\title{
Miranda
}

Revue pluridisciplinaire du monde anglophone /

Multidisciplinary peer-reviewed journal on the English-

speaking world

1 | 2010

Variations on Darwin

\section{Darwin in Wonderland: Evolution, Involution and Natural Selection in The Water Babies (1863)}

\section{Anne Chassagnol}

URL: http://journals.openedition.org/miranda/376

DOI: 10.4000/miranda.376

ISSN: 2108-6559

Publisher

Université Toulouse - Jean Jaurès

\section{Electronic reference}

Anne Chassagnol, "Darwin in Wonderland: Evolution, Involution and Natural Selection in The Water Babies (1863)", Miranda [Online], 1 | 2010, Online since 23 March 2010, connection on 16 February 2021. URL: http://journals.openedition.org/miranda/376 ; DOI: https://doi.org/10.4000/miranda.376

This text was automatically generated on 16 February 2021.

\section{(c) (i) (9)}

Miranda is licensed under a Creative Commons Attribution-NonCommercial-NoDerivatives 4.0 International License. 


\title{
Darwin in Wonderland: Evolution, Involution and Natural Selection in The Water Babies (1863)
}

\author{
Anne Chassagnol
}

1 In 2009, natural history museums worldwide showcased exhibitions on Evolution to celebrate the bicentenary of Charles Darwin's birth along with the $150^{\text {th }}$ anniversary of the publication of The Origin of Species. At the same time, Darwin's legacy appeared in bookshops, not only on every single shelf in the science section (Hodge), but also in sections devoted to art (Munro, Kort), education (Milner, Schanzer), travel, gardening (Boulter), cooking (Bateson) and, less surprisingly so, in literature (Padel, Hodge and Radick (eds)). Yet, hardly anything ${ }^{1}$ has been devoted to the influence of Darwin on children's literature. This neglect is nothing new. Even Gillian Beer's seminal work Darwin's Plots, published twenty-six years ago, appeared to suggest that Darwin's "big idea" impacted upon adult fiction first, referring to Middlemarch which was written in 1869, and Daniel Deronda published in 1876.

Darwin's theory is quite a fairy-like concept, concerning as it does metamorphosis and being discovered not with any technological instrument but rather through the meticulous observation of the fauna and flora of the quasi mythical islands of the Galapagos, among other places, and focusing frequently upon fantastical, often miniature, animals including larvae, beetles, bullfinches and butterflies. However, are we to assume that Darwin's tales had no impact whatsoever on children's fiction, which is incidentally peopled by many of the same beasts? The question I would like to raise here is whether children's fiction was not in fact the first literary genre to absorb Darwinian theory. Charles Dickens was one of the first authors to pay homage to Darwin with his article on "Species" in the 2 June edition of All the Year Round and a series of articles on "Natural Selection" in the 7 July edition of the same periodical. The Macmillan Magazine, one of the most celebrated journals for young readers, also devoted a specific section to evolutionary theory. Alice's Adventures in Wonderland (1865), not to 
mention Goblin Market (1862) by Christina Rossetti, show the evidence of their authors having digested Darwin's ideas years before they reached adult fiction.

If Charles Darwin's architectonic work famously triggered "the evolution revolution", it also inspired a novel genre that saw those influenced by him reinvent the idiom of fairyland by creating a new literary species-the scientific fairy tale in which fairies took the role of naturalists. The genre of scientific popularization which had already emerged in the eighteen ${ }^{\text {th }}$ century was to climax under Darwin's influence in the 1850 s. These books, often in the form of dialogue, were written by women, such as Jane Marcet (Conversation on Chemistry, 1806), Maria Edgeworth (Harry and Lucy, 1801), Margaret Gatty (Parables from Nature; Aunt Judy's Tales, 1859). They were designed to inform not only their female readers but also children, about the wonders of nature. Their work, which often referred to the writings of Erasmus Darwin rather than those of Charles, paved the way for post-Darwinian-inspired fantasy fiction, such as The Fairy Land of Science (1879) and Through Magic Glasses (1890) by Arabella Buckley, who was Sir Charles Lyell's secretary.

4 And it is for this reason that after the publication of The Origin of Species, dodos, fossils, barnacles, and shells, to cite but a few Darwinian specimens, came to colonise the pages of children's fantasy books, and that it became perfectly acceptable for fairy-tale heroes to debate the theories of Owen, Huxley and Darwin. This paper offers a natural selection of one of the best examples of the Fairy Science, Charles Kingsley's The Water Babies, also known as A Fairy Tale for a Land Baby. In addition, I will look at the use of Darwinian ideas in modern children fantasy writings. The Water Babies, which was published in 1863, that is four years after The Origin of Species, is probably one of the most celebrated Victorian fantasies for children. Unfortunately its success was outshone by the publication of Alice's Adventures in Wonderland in 1865 and by George MacDonald's The Light Princess (1864). Charles Kingsley (1819-1875) was a prolific writer of songs, poems, ballads and sermons. Some of his books, such as Westward Ho! (1855), The Heroes, or Greek Fairy Tales for My Children (1856) still hold a place in many Victorian anthologies today. Kingsley was also deeply interested in social reform and subsequently contributed articles for Politics for the People in 1848 and for The Christian Socialist in 1850, under the pseudonym of "Parson Lot." Although a distinguished academic, he was primarily known as a religious man, who became a minister in the church, before he was appointed chaplain in ordinary to Queen Victoria in 1859.

5 Darwin and Kingsley both went to Cambridge, but their periods of study did not overlap. Darwin (1827-1831) had already left Christ College when Kingsley (1832-42) was admitted to Madgalene. Their careers entered the limelight at practically the same time: Darwin published his research in 1859 while the next year, Kingsley was appointed Regius Professor in history, one of the most distinguished positions in Cambridge. Kingsley and Darwin were finally reunited through the debate on evolution and later exchanged a few letters on the subject. If Kingsley held radical positions both politically and religiously, he was also renowned for being an amateur naturalist. He was particularly fond of botany and geology, which he subsequently taught while he was a Canon in Chester. The influence of P.H. Gosse, the English naturalist, whom he befriended, encouraged him to study marine biology so much so that he even published Glaucus, or, The Wonders of the Shore (Merrill 216).

6 It is probably this aspect of Kingsley's career that prompted Darwin to submit to him for review an advanced copy of his manuscript. On 18 November, just a few days before 
the publication of The Origin of Species, Kingsley admitted having learnt to disbelieve the dogma of the permanence of species and offered to support Darwin. Thus he wrote to Darwin in the following terms:

That the Naturalist whom, of all naturalists living, I most wish to know \& to learn from, should have sent a socialist like me his book, encourages me at least to observe more carefully, \& think more slowly. All I have seen of it awes me; both with the heap of facts, \& the prestige of your name, \& also with the clear intuition, that if you be right, I must give up much that I have believed \& written. ${ }^{2}$

Kingsley welcomed the Theory of Evolution because he did not see it as an obstacle to faith. Rather, he famously believed that God did not just make the world, he made something much more wonderful, he made the world make itself. As a result, in the closing remarks of the second edition of The Origin of Species, Darwin added a quotation from his correspondence with Kingsley who was referred to anonymously as the "celebrated author and divine". If interpreting documents should revolve around trying to uncover not simply what a text says but as much what a text does, then the question one should ask here is what kind of an intervention does The Water Babies constitute? In these terms, The Water Babies is an attempt to adapt Darwinian theory to the unexpected medium of the fairy tale to show that science and religion as well as fiction can coexist in a coherent environment and explain the large and complex in terms of the small and simple. Given that a controversial aspect of Darwin's theory was to understand how humankind related to the animal kingdom, Kingsley illustrates this debate by transforming Tom into a creature halfway between humanity and animality.

The Water Babies is the story of Tom, a chimney-sweeper who sets off to a mansion with his master to accomplish his painstaking and dismal duty. However, he loses his way in the maze of flues and accidentally falls down, covered in soot, into the bedroom of Ellie, the sleeping beauty in residence. While she is still asleep, he catches a glimpse of his image in the mirror and, much to his horror, discovers that he is but "a little black ape" (Kingsley 26). He will later be referred to as "a small black gorilla fleeing in the forest" (Kingsley 31). Slowly, the Darwinian subtext weaves itself into the main text. The little girl awakes and screams. The entire household is then sent out to pursue the alleged burglar who makes a narrow escape through the fields and falls down a cliff into a stream where he is believed to have drowned. This is when and where the adventure begins, as Tom has now become a water baby, that is to say that he has regressed into an embryonic form of his own self. His trials and tribulations among all kinds of Darwinian creatures occur under the close supervision of two very unusual fairies, Mrs Bedonebyasyoudid, acting for Law, and Mrs Doasyouwouldbedoneby, acting for Love. The Water Babies is anything but a traditional fairy tale. It is a puzzling story where facts and fictions coalesce and where fictitious characters and famous scientists coexist. Darwin himself is mentioned once in the course of the novel in a key passage, which serves to justify the existence of a strange species, that of the water babies. Therefore, the tale is presented as if it were a scientific demonstration proving their existence, as the following extract indicates:

You must not say that this cannot be, or that that is contrary to nature. You do not know what Nature is, or what she can do; and nobody knows; not even Sir Roderick Murchison, or Professor Owen, or Professor Sedgwick, or Professor Huxley, or Mr. Darwin, or Professor Faraday, or Mr. Grove, or any other of the great men whom good boys are taught to respect. They are wise men; and you must listen respectfully to all they say: but even if they should say, which I am sure they would, 
"that cannot exist. That is contrary to nature," you must wait a little, and see; for perhaps even they may be wrong. (Kingsley 69-70)

All the scientists aforementioned were already well known for their intervention in the debate on evolution. Sir Roderick Murchison and Adam Sedgwick were both members of the Royal Society and leading geologists who both taught Darwin at Cambridge. Richard Owen, on the other hand, was a biologist and a paleontologist who studied prehistoric creatures, the Nautilus and the Archeopterix, and famously coined the word "dinosaur". Kingsley mocks the debate over evolution by re-enacting the tensions and lengthy discussions of figures representing different schools of thought as he refers to Sir Roderick Murchison, Professor Owen, Professor Sedgwick, Professor Huxley, Mr. Darwin, M. Du Chaillu, etc. There is a very famous illustration in one of the editions of the tale in which Owen and Huxley are closely examining a specimen of a water baby that had been previously fished out of the sea and brought to their laboratory. If Darwin challenges man's place in the animal kingdom, Kingsley literally translates this idea by transposing the vertical hierarchy of the great chain of beings along a horizontal stream as Tom encounters all types of Darwinian creatures underwater. His odyssey is described as a struggle for life and Tom is depicted as a wild animal which has to fend for itself if it wants to survive: "He is but a savage now, and like the beasts which perish; and from the beasts which perish he must learn" (Kingsley 58). Kingsley satirizes the very technical terminology that was used at the time by scientists, and subsequently by evolutionists in particular, in chapter IV, where an old fairy puts a spell on the professor who discovers the first species of water babies. As he refuses to believe in their existence, the fairy fills his head with all sorts of imaginary creatures so much so that doctors are called in to make the following diagnosis:

But at last the majority agreed on a report in the true medical language, one half bad Latin, the other half worse Greek, and the rest what might have been English, if they had only learnt to write it. And this is the beginning thereof-

"The subanhypaposupernal anastomoses of peritomic diacellurite in the encephalo digital region of the distinguished individual of whose symptomatic phoenomena we had the melancholy honour (subsequently to a preliminary diagnostic inspection) of making an inspectorial diagnosis, presenting the interexclusively quadrilateral and antinomian diathesis known as Bumpsterhausen's blue follicles, we proceeded"-(Kingsley 163).

Kingsley later mentions "the hippopotamus major", a play on the word hypothalamus, which was the bone of contention in the evolutionist debate, given that some believed, according to Kingsley, that "apes had hippopotamus majors in their brains just as men have" (Kingsley 153). Kingsley parodies most of the notions that Darwin defined in the course of the 14 chapters of The Origin of Species, such as variation, selection, and adaptation (Hodgson). When Tom wakes up underwater he is no longer a little boy but an embryo-measuring 3.8 inches-which has adapted to its new environment by developing external gills. Adaptation is also approached through the episode of the salmon and the trout. Tom encounters both fish, but the former confesses how much he despises the trout:

My dear, we do not even mention them, if we can help it; for I am sorry to say they are relations of ours who do us no credit. A great many years ago they were just like us: but they were so lazy, and cowardly, and greedy, that instead of going down to the sea every year to see the world and grow strong and fat, they chose to stay and poke about in the little streams and eat worms and grubs; and they are very properly punished for it; for they have grown ugly and brown and spotted and small; and are actually so degraded in their tastes, that they will eat our children. (Kingsley 125) 
11 Thus, according to the tale, the trout, seems to have adapted driven by its laziness while the salmon seemed to have remained the same. Variation is another Darwinian concept that Kingsley parodies at the very beginning of the book, when Tom has not yet transformed into a water baby. As he is rolling down a hill, he encounters a beetle ${ }^{3}$ and Tom, being covered in soot, accidentally "dirti[es] everything terribly" (Kingsley 50), and leaves a black smudge on the insect which will be affected for generations. As a result, "there have been more black beetles in Vendale since than ever were known before; all, of course, owing to Tom's having blacked the original papa of them all" (Kingsley 50). It must be said that the evolution process recounted in this passage owes more to Lamarck than Darwin. Darwin invited his readers to rethink what he calls "the whole economy of nature" (Darwin 1859,49 ) by accepting that nature is animated by a constant struggle for existence. He urges us to remember that "birds which are idly singing around us mostly live on insects or seeds, and are thus constantly destroying life" (Darwin 1859, 50). This same struggle for life is depicted in The Water Babies when the dragon-fly eats the gnats that Tom had befriended or when the trout "rushed from among the stones, and began gobbling the beetles and leeches in the most greedy and quarrelsome way, and swimming about with great worms hanging out of their mouths, tugging and kicking to get away from each other" (Kinsgley 111).

Later in the tale, Kingsley particularly focuses on mutation, whereby animals are depicted either while they are in full transformation or while their species is dying out. In chapter VII, Tom is confronted with a certain Lady Gairfowl, who is the very last descendant of her kind and whose wings have shrunk to such an extent that she is unable to fly anymore and uses them merely to fan herself. Her linguistic skills are so affected by her physical change that she seems to confuse the verbs to swim and to fly, which have now become useless in her own vocabulary. In fact, Tom later discovers that this particular species, which used to be "a great nation, and spread over all the Northern Isles" (Kingsley ${ }^{250)}$, has been decimated by climate change and by sailors who shot them and took their eggs. As the birds were unable to adapt, the species became extinct.

13 Tom also discovers degeneration and the ill-adaptation of certain species, such as the famous Doasyoulikes. These creatures have been living in "the land of Readymade, at the foot of the Happy-go-lucky Mountains" (Kinsgley 229) far away from any serious predators. They were a refined civilisation, they were very fond of music but never had to worry about food. They just sat under the vines and "squeezed the grape juice down their throats [...] and waited till the pigs ran against their mouths, and then took a bite, and were content" (Kinsgley 231). However, the eruption of a volcano decimated part of their population and most of those who remained, too lazy to even envisage leaving the premises that were burnt to a cinder, died of hunger. The survivors were the perfect example of involution as, 500 years later, they were forced to hang on trees, making nests to keep off the rain as, underneath, the tree lions were prowling about. The poor foolish creatures had grown so stupid now, that they could hardly think. As a result, they became apes. Apes, of course, were at the centre of the debate on evolution. Famously, the whole controversy on natural selection as applied to humankind could be imputed to a misinterpretation of a sentence regarding these very same mammals in Darwin's work. The explorer Paul Du Chaillu also contributed to the "monkeymania" which followed, by giving a famous lecture at the Royal Institution and infamously organised a tour throughout England to exhibit decapitated ape heads in 1860 
(Hodgson 232-3). The story of the Doasyoulikes is used as an example by Ellie, the little girl whom Tom woke up at the beginning of the tale. She somehow follows his adventures and is dispatched by the fairy to put Tom on the right track. Here her story serves a moral purpose because, if the extinction of the Doasyoulikes is linked to their moral degeneration, conversely, Tom can only evolve if his behaviour is irreproachable and in line with the Christian moral values. Eventually, Tom will grow up to be a great man of science. He will indeed become clean, obedient and a good Christian. Kingsley's demonstration is thus complete: the evolution of water babies is a living testimony that, as a human species, they are superior to other animals, essentially because they are endowed with moral qualities.

More recently, Philip Pullman, to a certain extent, tinkers with Darwinism, especially in The Amber Spyglass. The final novel in the series His Dark Materials, features the Mulefa, curious animals which "looked like a cross between antelopes and motorcycles" (Pullman 445). They are discovered accidentally by the biologist Mary Malone, who travels into parallel, and yet different, universes in search of shadow particles. The very existence of multiple worlds also suggests multiple stages of evolution:

If her guess about these universes was right, and they were the multiple worlds predicted by quantum theory, then some of them would have split off them from her own much earlier than others. And clearly in this world evolution had favoured enormous trees and large creatures with a diamond-framed skeleton (Pullman 90).

In that respect, the Mulefa, unlike the grazing animals that Mary Malone encountered on the prairie during the course of her travels, have adapted quite differently to their environment. As an expert on biology, which, according to Richard Dawkins, is "the study of complicated things that give the appearance of having been designed for a purpose" (Dawkins 1), Mary Malone is able to decipher the function of the Mulefa's design:

They were roughly the same size as the grazing creatures, but leaner and greycoloured, with horned heads and short trunks like elephants'. They had the same diamond-shaped structure as the grazers, but somehow they had evolved, on their fore and rear single legs, a wheel.

[...] The wheels were seed-pods. Perfectly round, immensely hard and light-they couldn't have been designed better. The creatures hooked a claw through the centre of the pods with their front and rear legs, and used their two lateral legs to push against the ground and move along. (Pullman 91-2)

The Mulefa's survival depends on the seed-pods, just as the trees producing them need the assistance of the Mulefa to crack the seed open, thus contributing to the germination of future trees. Notwithstanding the trace of the Darwinian influence in Pullman's trilogy, His Dark Materials actually seems to owe more to Richard Dawkins' interpretation of Darwinism. Pullman's Oxford being also Dawkins' Oxford, their works, which both focus on faith, seem to echo one another. Pullman wrote a chapter on Dawkins' writing, entitled "Every indication of inadvertent solicitude" in the edited collection Richard Dawkins: How a Scientist Changed the Way We Think (Grafen and Rifley), while Dawkins is rumoured to be currently working on a children's book. One may wonder if the search for "Dust", or shadow particles, in His Dark Materials was not a response to The Blind Watchmaker, in which Dawkins studied complexity and design, and concluded:

Our brains were designed to understand [...] a world of medium-sized objects moving in three dimensions at moderate speeds. We are ill-equipped to comprehend the very small and the very large; things whose duration is measured 
in picoseconds or gigayears; particles that don't have position; forces and fields that we cannot see or touch [...]. (Dawkins 2) the award-winning Mortal Engines. In this quartet, populations grow to outstrip available resources, and Philip Reeve, a writer and cartoonist, adapts the theories of Darwin and Malthus to conceive a post-apocalyptic steampunk universe in which fastdeveloping metropolises, called "Traction Cities", as they are built on gigantic wheels and propelled by engines and sails, have to feed on other smaller cities-usually static settlements-if they want to survive. Bordeaux, "Montpelier" and Paris are all Traction Cities, opposed to the anti-traction league. Reeve reinvents Darwinism in the light of what he calls "Municipal Darwinism", a parody of natural selection in an architectural kingdom where cities chase towns, and where the struggle for existence becomes a fight for urban expansion:

It was natural that cities ate towns, just as the towns ate smaller towns, and smaller towns snapped up the miserable static settlements. That was Municipal Darwinism, and it was the way the world had worked for a thousand years, ever since the great engineer Nicholas Quirke had turned London into the first Traction City. (Reeve 10)

According to Darwin, "Natural Selection [...] is a power incessantly ready for action" (Darwin 1859, 49), and Reeve employs the word "power" in a more mechanical sense to refer to engines and hydraulic jaws. In addition the concept of the survival of the fittest is transposed into one of "a chase" in which cities move at an astonishing speed. There is also a parody of social Darwinism at play as the populations who have been captured and swallowed by the triumphant cities are then sent to a place called "the Gut", somewhere in "the Digestion Yards", where defeated cities are dismantled. Competition among individuals appears between scavengers, known as "Salvagemen" who swagger among the heaps of waste to eliminate townless wanderers.

Darwin's ideas, against all odds, also resurfaced in the online role-playing video game World of Warcraft. My point here is not to debate the quality of this game but rather, simply, to suggest that it reinvents evolutionary theory by interpreting the survival of the fittest concept on a variety of levels. As an interactive game, World of Warcraft is a real-time strategy game where players can eliminate one another by assuming the identity of one of the ten playable races, including Gnomes, Orcs, Blood Elves or Trolls. Moreover, the game itself is something of a mutant species, as players can alter the profile of a set character and the best players can even modify the game, should they survive epidemics such as "the corrupted blood plague", etc.

As illustrated by The Water Babies (still published today in an abridged version, which unfortunately does not feature the scientific dimension of the tale) and more recently by the works of Philip Pullman and Philip Reeve, Darwin's theories have ever been present in children's fiction. What is truly wonderful in these Darwinian literary wonderlands, Darwin being himself a lord of language, does not lie in the adaptation of the Darwinian text. Darwin's "big idea" is arguably the most wonderful idea ever, in its true fantastical sense of the term. And like all the best ideas, whether scientific or literary, it is remarkably simple, "childishly so", according to Richard Dawkins (Dawkins xix). Charles Darwin began his tale "once upon a time," and the last word of The Origin of Species is "evolved." True to its promise, his legacy did evolve happily ever after, launching a debate which still resonates today, both in science and in literature. ${ }^{4}$ 


\section{BIBLIOGRAPHY}

Bateson, Dusha. Mrs Charles Darwin's Recipe Book: Revived and Illustrated. New York: Glitterati, 2008.

Boulter, Michel. Darwin's Garden: Down House and the Origin of Species. Berkeley: Counterpoint, 2009.

Darwin, Charles. The Autobiography of Charles Darwin. Whitefish, Mont.: Kessinger Publishing Rare Reprints, 2003.

---. On the Origin of Species by Means of Natural Selection, or the Preservation of favoured races in the struggle for life. 1859. Harmondsworth: Wordsworth Classics, 1998.

Dawkins, Richard. The Blind Watchmaker. 1986. London: Penguin, 2006.

Hodge, Jonathan, Radick, Gregory (eds.). The Cambridge Companion to Darwin. $2^{\text {nd }}$ ed. Cambridge: Cambridge University Press, 2009.

Grafen, Alen, Ridley, Mark. Richard Dawkins: How a Scientist Changed The Way We Think. Oxford: Oxford University Press, 2006.

Hodge, MJS. Darwin Studies: A theorist and his Theories in their Contexts. Aldershot: Ashgate, 2009.

Hodgson, Amanda. "Defining the Species: Apes, Savages and Humans in Scientific and Literary Writing of the 1860s." Journal of Victorian Culture, 4.2 (1999): 228-252.

Kingsley, Charles. The Water Babies. 1863. Harmondsworth: Penguin Popular Classics, 1995.

Kort, Pamela, Holbein, Max. Darwin Art and the Search for Origins. Stuttgart: Art Stock Books, 2009.

Lawson, Kristan. Darwin and Evolution for Kids with 21 Activities: His Life and Ideas. Chicago: Chicago Review Press, 2009.

Markle, Sandra. Animals Charles Darwin Saw: an Around the World Adventure. San Francisco:

Chronicle Books, 2009.

Merrill, Lynn M. The Romance of Victorian Natural History. Oxford: Oxford University Press, 1989.

Milner, Richard, Tattersall, Ian, Jay Gould, Stephen. Darwin's Universe: Evolution from A to Z.

Berkeley: University of California Press, 2009.

Munro, James, Donald Diana. Endless Forms: Charles Darwin, Natural Science and the Visual Arts. New Haven, Conn.; London: Yale: University Press, 2005.

Padel, Ruth. Darwin: A Life in Poems. London: Chatto \& Windus, 2009.

Pullman, Philip. The Amber Spyglass. London: Scholastic Press, 2000.

Reeve, Philip. Mortal Engines. London: Scholastic Press, 2001.

Schanzer, Rosalyn. What Darwin Saw: The Journey that Changed the World. Washington: National Geographic, 2009.

Stove, David. Darwinian Fairy Tales: Selfish Genes, Errors of Heredity, and Other Fables of Evolution. Aldershot: Ashgate, 1996. 


\section{NOTES}

1. Darwin's bicentenary generated a whole series of books on his life and experiments (Lawson, Markle). But very few contemporary authors have attempted to adapt Darwin's ideas to children's fiction.

2. Letter 2534 - Kingsley, Charles to Darwin, C. R., 18 Nov 1859. hhttp://www.darwinproject.ac.uk/

3. The beetle is a very emblematic creature in Darwin's animal kingdom. There is a curious incident involving this particular insect which is mentioned in his Autobiography: "one day, on tearing off some old bark, I saw two rare beetles and seized one in each hand; then I saw a third and new kind, which I could not bear to lose, so that I popped the one which I held in my right hand into my mouth. Alas it ejected some intensely acrid fluid, which burnt my tongue so that I was forced to spit the beetle out, which was lost, as well as the third one" (Darwin 2003, 15).

4. It is interesting to note that, while Darwin was often praised for the quality of his prose and while he uses the vocabulary of wonder to convey his ideas, his detractors, such as Creationists, or David Stove's Darwinian Fairy Tales have turned these arguments against Darwin to claim that his theory is nothing but a badly written fairy tale.

\section{ABSTRACTS}

Why does Alice meet a Dodo? Why did Victorian fairies stop performing their traditional functions in the 1860s and take on the role of naturalists? If Charles Darwin famously triggered the evolution revolution, he also inspired a novel genre that saw his followers reinvent the idiom of fairyland by creating a new literary species: the scientific fairy tale. After the publication of The Origin of Species, dodos, fossils, shells and tortoises, to cite but a few Darwinian specimens, came to colonise the pages of children's fantasy books, and fairy-tale heroes subsequently debated the theories of Richard Owen, Thomas Huxley and Charles Darwin. This paper wishes to present a natural selection of one of the best examples of the Fairy Science, such as Charles Kingsley's The Water Babies and will also focus on the use of Darwinian ideas in modern children fantasy writings.

Pourquoi Alice fait-elle la connaissance d'un dodo ? Comment expliquer que les fées aient changé de fonction dans la littérature victorienne post-darwinienne pour endosser le rôle de naturalistes. Si les théories de Darwin sur l'évolution ont profondément modifié la pensée scientifique et les croyances religieuses, Darwin est aussi à l'origine d'une nouvelle espèce littéraire, le conte de fées scientifique. C'est pourquoi après la publication de L'Origine des espèces, dodos, fossiles, coquillages et tortues, pour ne citer que quelques spécimens darwiniens, ont colonisé les pages de recueils de fantasy victorienne, tandis que les héros de contes de fées débattaient les théories darwiniennes. Cet article a pour but de présenter une sélection naturelle des meilleurs exemples littéraires de ce que l'on a pu appeler des contes de fées scientifiques, comme The Water Babies de Charles Kingsley. Il sera également question de l'influence darwinienne dans des ouvrages plus récents de littérature de jeunesse. 
INDEX

Keywords: Darwinism, evolution, natural selection, Victorian fairy tales, Darwin

Mots-clés: darwinisme, évolution, sélection naturelle, contes de fées victoriens, Darwin

\section{AUTHORS}

\section{ANNE CHASSAGNOL}

Maître de conférences

Université Paris 8 Vincennes Saint-Denis

annechassagnol@hotmail.com 